\title{
Effect of PM2.5 on invasion and proliferation of HeLa cells and the expression of inflammatory cytokines IL-1 and IL-6
}

\author{
KAIQING HUANG ${ }^{1-3}$, WENXIANG LI ${ }^{4}$, YANHONG CHEN ${ }^{1-3}$ and JINYAN ZHU ${ }^{1-3}$ \\ ${ }^{1}$ Department of Gynecology, The Third Affiliated Hospital of Guangzhou Medical University; \\ ${ }^{2}$ Key Laboratory of Reproduction and Genetics of Guangdong Higher Education Institutes; \\ ${ }^{3}$ Key Laboratory for Major Obstetric Diseases of Guangdong Province, Guangzhou, Guangdong 510150; \\ ${ }^{4}$ Maternal and Child Health Care Hospital of Nanning, Nanning, Guangxi 530011, P.R. China
}

Received November 29, 2017; Accepted August 28, 2018

DOI: $10.3892 / \mathrm{ol} .2018 .9516$

\begin{abstract}
Effects of different levels of PM2.5 on invasion and proliferation of HeLa cells and the expression levels of inflammatory cytokines IL-1 and IL-6 under $10 \mu \mathrm{g} / \mathrm{ml}$ PM2.5 were investigated. Different groups of HeLa cells were treated with PM2.5 at $0,10,25,50,100$ and $200 \mu \mathrm{g} / \mathrm{ml}$ for $36 \mathrm{~h}$, respectively. Cell proliferation was detected by MTT assay. Transwell assay was performed to detect the invasion of HeLa cells. Enzyme-linked immunosorbent assay (ELISA), RT-qPCR and western blotting were used to detect the expression levels of inflammatory cytokines IL-1 and IL-6 in PM2.5-stimulated HeLa cells. It was observed that proliferation of cells treated with PM2.5 at a concentration of $10 \mu \mathrm{g} / \mathrm{ml}$ was basically the same as that of untreated cells, while high concentration of PM2.5 inhibited the proliferation of HeLa cells in a dose-dependent manner in the range from 25 to $200 \mu \mathrm{g} / \mathrm{ml}(\mathrm{P}<0.05)$. Transwell invasion assay showed that the number of migrating HeLa cells stimulated by $10 \mu \mathrm{g} / \mathrm{ml}$ PM2.5 was significantly greater than that of $\mathrm{NC}$ group cells $(\mathrm{P}<0.05)$. Western blotting showed that IL-1 and IL-6 protein expression levels in HeLa cells after stimulation with $10 \mu \mathrm{g} / \mathrm{ml}$ PM2.5 were significantly higher than that in NC group $(\mathrm{P}<0.05)$. RT-qPCR results also showed that IL-1 mRNA and IL-6 mRNA expression levels in HeLa cells stimulated by $10 \mu \mathrm{g} / \mathrm{ml}$ PM2.5 were significantly higher than those in the $\mathrm{NC}$ group $(\mathrm{P}<0.05)$. Additionally, ELISA results showed that IL-1 and IL-6 levels in HeLa cells stimulated by $10 \mu \mathrm{g} / \mathrm{ml} \mathrm{PM} 2.5$ were significantly higher than those in $\mathrm{NC}$ group $(\mathrm{P}<0.05)$. We conclude that high concentrations of PM2.5 can inhibit the proliferation of HeLa cells to a certain extent. Stimulation with $10 \mu \mathrm{g} / \mathrm{ml}$ PM2.5 increases the
\end{abstract}

Correspondence to: Dr Kaiqing Huang, Department of Gynecology, The Third Affiliated Hospital of Guangzhou Medical University, 63 Duobao Road, Guangzhou, Guangdong 510150, P.R. China E-mail: hpyq84@163.com

Key words: PM2.5, HeLa cells, invasion, proliferation, IL-1, IL-6 invasion ability of HeLa cells and promotes the expression of inflammatory cytokines IL-1 and IL-6.

\section{Introduction}

PM2.5 refers to the suspended particles in the air with a diameter $\leq 2.5 \mu \mathrm{m}$. PM2.5 can stay in the air for a long time, and high concentration of PM2.5 can lead to serious air pollution. With special morphological and physical properties, PM2.5 can enter the bloodstream through the respiratory tract to cause reproductive toxicity, and increase the incidence of cancer (1-4). PM2.5 was first recognized as a type of carcinogen by the World Health Organization in October 2013. PM2.5 can induce a variety of malignancies including brain tumors, leukemia and cervical cancer. Studies have shown that long-term exposure to PM2.5 can reduce life expectancy, and can also increase the incidence of a variety of chronic diseases, such as asthma, bronchitis and cardiovascular disease (5-8).

IL-1 is an important immunomodulatory factor that plays important roles in regulating the immune function of cells, and participates in the endocrine system, nervous system and the inflammatory reaction in the human body (9). IL-6 is a type of inflammatory factor that plays a pivotal role in female reproductive tract infections and is expressed in cervical epithelial cells, renal cell carcinoma epithelial cells, and multiple myeloma tissues (10). It has been reported that (11) PM2.5 inhalation can cause lymphocyte aggregation, neutrophil infiltration and other inflammatory reactions. Inflammatory cytokines IL-1 and IL-6 promote cell aggregation, and the levels of IL-1 and IL-6 reflect early inflammatory reaction in the human body (12). In this study, HeLa cells were stimulated by PM2.5 to observe the effects of PM2.5 on proliferation and invasion of HeLa cells and on the expression levels of IL-1 and IL-6.

\section{Materials and methods}

Main reagents and equipment. HeLa cells (The Institute of Basic Medical Sciences of the Chinese Academy of Medical Sciences, Beijing, China); RPMI-1640 medium (R8758; Sigma-Aldrich; Merck KGaA, St. Louis, MO, USA); 
trypsin (15400054; Gibco; Thermo Fisher Scientific, Inc., Carlsbad, CA, USA); fetal bovine serum (04-001-1ACS; Shanghai Enzyme-linked Biotechnology Co., Ltd., Shanghai, China); rabbit anti-human IL-1 and IL-6 monoclonal antibodies, horseradish peroxidase, goat anti-rabbit IgG secondary antibody, and IL-1 and IL-6 enzyme-linked immunosorbent assay (ELISA) kit (701304, 701028, MA110371, A-11034, KHC0011, BMS213-2; Thermo Fisher Scientific, Inc.). TRIzol reagent and RT-PCR kit (15596018; Invitrogen; Thermo Fisher Scientific, Inc.). Reverse transcription kit and TaqMan miRNA kit (4374966; Applied Biosystems; Thermo Fisher Scientific, Inc.). High-speed refrigerated centrifuge (AVANTIJ-15R; Beckman Coulter, Inc., Brea, CA, USA). Microplate reader (51119700DP; Gibco; Thermo Fisher Scientific, Inc.). Constant temperature $\mathrm{CO}_{2}$ incubator and $\mathrm{ABI} 7900$ real-time PCR instrument (Applied Biosystems; Thermo Fisher Scientific, Inc.).

The study was approved by the Ethics Committee of the Third Affiliated Hospital of Guangzhou Medical University (Guangzhou, China).

Preparation of PM2.5 turbid liquid and particle treatment. A piece of glass fiber filter paper $(200 \times 250 \mathrm{~mm})$ was placed in a thermostat at $100^{\circ} \mathrm{C}$ for $1-2 \mathrm{~h}$. During sampling, filter paper was placed on the filter paper holder with tweezers and fixed. The flow rate of the sampler was controlled between 1.1 and $1.7 \mathrm{~m}^{3} / \mathrm{min}$. After sampling, the filter paper was collected and placed in a desiccator for $6 \mathrm{~h}$. The filter paper containing the particles was cut into $1-\mathrm{cm}^{2}$ pieces and immersed in three kinds of steam water. Ultrasonic oscillation was performed 4 times, $30 \mathrm{~min}$ per time. Then fluid was filtered through 6 layers of gauze, followed by centrifugation at $10,000 \times \mathrm{g}, 4^{\circ} \mathrm{C}$ for $20 \mathrm{~min}$. Suspension was collected in a glass plate, vacuum frozen, vacuum dried, and stored in a low temperature freezer. A certain amount of sample was mixed with DMEM cell culture, followed by ultrasonic oscillation for $15 \mathrm{~min}$. Stock solution was sterilized and stored at $4^{\circ} \mathrm{C}$. Ultrasonic oscillation for another $5 \mathrm{~min}$ was performed before use (13).

Cell culture and treatment. HeLa cells were collected during logarithmic growth phase, and were digested with $0.25 \%$ trypsin. Cells were resuspended in cell culture medium containing $10 \%$ fetal bovine serum to a final density of $2.5 \times 10^{5} / \mathrm{ml}$. After incubation for $24 \mathrm{~h}$, the cells were washed 3 times with PBS. Finally, $20 \mu \mathrm{l}$ of particle suspension were added for the final concentrations of $0,10,25,50$, 100 and $200 \mu \mathrm{g} / \mathrm{ml}$, respectively. Concentration of $0 \mu \mathrm{g} / \mathrm{ml}$ was used as negative control. Each treatment was repeated 3 times, and the cells were cultured in an incubator $\left(37^{\circ} \mathrm{C}\right.$, $\left.5 \% \mathrm{CO}_{2}\right)$.

MTT assay to detect cell proliferation. HeLa cells at a density of $4.5 \times 10^{3}$ cells $/ \mathrm{ml}$ were transferred to a 96 -well plate with $200 \mathrm{ml}$ in each well. Three replicate wells were set for each experiment. The cells were cultured in an incubator $\left(37^{\circ} \mathrm{C}\right.$, $\left.5 \% \mathrm{CO}_{2}\right)$ for $4 \mathrm{~h}$, followed by the addition of $20 \mu \mathrm{l}(5 \mathrm{mg} / \mathrm{ml})$ of MTT reagent into each well. After cell culture for another $5 \mathrm{~h}$, supernatant was removed and $200 \mathrm{ml}$ DMSO were added. After shaking for $15 \mathrm{~min}$, a microplate reader (490 nm) was used to read the OD values and the cell growth curve was plotted.

Transwell assay. Cell invasion ability was measured by Transwell assay. Briefly, $80 \mu 1$ of diluted Matrigel solution were used to cover the entire upper membrane. After keeping at room temperature for $1.5 \mathrm{~h}, 500 \mu \mathrm{l}$ cell culture medium containing $20 \%$ FBS were added to the lower chamber, while HeLa cells $\left(4 \times 10^{3}\right)$ in serum-free medium were added into the upper chamber. After incubation for $24 \mathrm{~h}$, the cells that failed to invade the membranes were removed and $\mathrm{H} \& \mathrm{E}$ staining was performed. Three visual fields were selected under an optical microscope to count the cells 3 times.

Western blotting. Total protein was extracted from the collected cells using RIPA pyrolysis (P0013B; Beyotime Institute of Biotechnology, Shanghai, China). BCA method (P0009; Beyotime Institute of Biotechnology) was used to detect the protein concentration, and the calculated protein was added to $5 \mathrm{X}$ SDS sample buffer at 1/4 volume. For SDS-PAGE electrophoresis separation, the constant voltage was $80 \mathrm{~V}$ at $8 \%$ stacking gel, and it was changed to $120 \mathrm{~V}$ at $5 \%$ separate gel; in the ice bath at $80 \mathrm{~V}$ for $100 \mathrm{~min}$. The membrane was transferred to difluoroethylene film, the protein bands were dyed with Ponceau S., washed after soak in PBST for 5 min and stored in $5 \%$ skimmed milk powder at $4{ }^{\circ} \mathrm{C}$ for the night. After the antibodies were diluted with PBST containing $1 \%$ skimmed milk powder, IL-1, IL-6 monoclonal antibodies $(1: 1,000)$ were added and sealed at $4^{\circ} \mathrm{C}$ for the night. After the primary antibody was removed, the membrane was washed with TBST, and horseradish peroxidase labeled goat anti-rabbit secondary antibody $(1: 5,000)$ was added. It was incubated at $37^{\circ} \mathrm{C}$ for $1-2 \mathrm{~h}$, and rinsed 5 times with TBST, 5 min each time. Developed in the darkroom, the liquid was blotted on the film with filter paper, ECL gloss agent (Beyotime Institute of Biotechnology) was applied, and exposed after $5 \mathrm{~min}$. The gray value was analyzed using Quantity One software (Bio-Rad Laboratories, Inc., Hercules, CA, USA) by scanning protein bands, where the relative expression level of protein was equal to the gray value of target protein bands/GAPDH protein bands.

$R T$-qPCR. The collected cells were extracted with TRIzol for total RNA extraction, and the extracted total RNA was tested for purity, concentration and integrity using ultraviolet spectrophotometry and agarose gel electrophoresis. Total RNA was reverse transcribed using a reverse transcription kit, and the operation steps were strictly followed according to the manufacturer's instructions. cDNA preservation of reverse transcription was collected and part was taken for subsequent experiments. PCR kits were used for PCR amplification experiments, and the PCR reaction system was $2 \mathrm{X}$ TransStart ${ }^{\circledR}$ Top Green qPCR SuperMix (TransGen Biotech, Beijing, China) $10 \mu 1$, upstream and downstream primers (each $0.4 \mu \mathrm{l}$ ), cDNA $2 \mu 1,50 X$ ROX Reference Dye II (Thermo Fisher Scientific, Inc.) $0.4 \mu \mathrm{l}$. nuclease-free water was added to complete to $20 \mu \mathrm{l}$. The PCR reaction conditions were: $95^{\circ} \mathrm{C}$ predegeneration for $30 \mathrm{sec}, 95^{\circ} \mathrm{C}$ for $5 \mathrm{sec}, 60^{\circ} \mathrm{C}$ for $30 \mathrm{sec}$ and 40 cycles. Three duplicate wells were set for each sample, and the experiment was conducted three times. In this study, GAPDH was 
Table I. Primer sequences

\begin{tabular}{lll} 
Gene & \multicolumn{1}{c}{ Upstream primers } & Downstream primers \\
\hline IL-1 & 5'-GCACAGTTCCCCAACTGGTA-3' & 5'-AAGACACGGGTTCCATGGTG-3' \\
IL-6 & 5'-TTCGGCAAATGTAGCATC-3' & 5'-AATAGTGTCCTAACGCTCATAC-3' \\
GAPDH & 5'-GGCACAGTCAAGGCTGAGAATG-3' & 5'-ATGGTGGTGAAGACGCCAGTA-3'
\end{tabular}

used as internal reference, and $2^{-\Delta \mathrm{Cq}}$ was used to analyze the data (14) (Table I).

ELISA. According to the manufacturer's instructions, the test was performed as follows: the collected cells were added to $50 \mu \mathrm{l}$ of standard substance solution at different concentrations in blank micropores; $50 \mu \mathrm{l}$ of distilled water were added to the blank control well and $50 \mu \mathrm{l}$ of antibody were added. In the rest of the micropores, $40 \mu \mathrm{l}$ of the sample were firstly added and then $10 \mu \mathrm{l}$ of the biotin-labeled antibody were added. The plate was sealed and incubated at $37^{\circ} \mathrm{C}$ for $30 \mathrm{~min}$. When the plate was washed in each well, it was ensured that it was full and not overflowing; it was left to stand for $30 \mathrm{sec}$, discarded and patted dry, 5 times in total. After $50 \mu$ l enzyme-labeled solution was added to each hole, the plate was sealed again and incubated at $37^{\circ} \mathrm{C}$ for $60 \mathrm{~min}$. The plate was washed again for 5 times, and patted dry with absorbent paper at the last time. A total of $100 \mu \mathrm{l} /$ well horseradish peroxidase marker was added before sealing the plate and incubated in the dark under $37^{\circ} \mathrm{C}$ for $15 \mathrm{~min}$. Another $100 \mu \mathrm{l} /$ well chromogenic substrate TMB was added, and incubated in the dark at room temperature for $20 \mathrm{~min}$. Finally, $50 \mu \mathrm{l} /$ well stop buffer was added, and enzyme standard instrument was used for testing within $15 \mathrm{~min}$. The maximum absorption wavelength of $450 \mathrm{~nm}$ was measured. Three sets of repeat wells were set, and the experiment was repeated for 3 times.

Statistical analysis. SPSS 20.0 software package (IBM Corp., Armonk, NY, USA) was used for the statistical analysis of the collected data and GraphPad Prism 5 software (GraphPad Software, Inc., La Jolla, CA, USA) for the figures. Measurement data were expressed as mean \pm standard deviation (mean $\pm \mathrm{SD}$ ), and were compared by t-test (between two groups) and one-way analysis of variance (among multiple groups). LSD test was used as a post hoc test. Repeated analysis of variance was used for comparisons among multiple time-points. $\mathrm{P}<0.05$ was considered to indicate a statistically significant difference.

\section{Results}

Effects of different concentrations of PM2.5 on HeLa cell proliferation. The results showed that PM2.5 at $10 \mu \mathrm{g} / \mathrm{ml}$ had no significant effect on cell proliferation, while PM2.5 inhibited the proliferation of HeLa cells at the concentrations of $50-120 \mu \mathrm{g} / \mathrm{ml}$, in a concentration-dependent manner $(\mathrm{P}<0.05)$ (Fig. 1).

Effects of PM2.5 on the invasion of HeLa cells as detected by Transwell assay. We detected the migration of cells in two

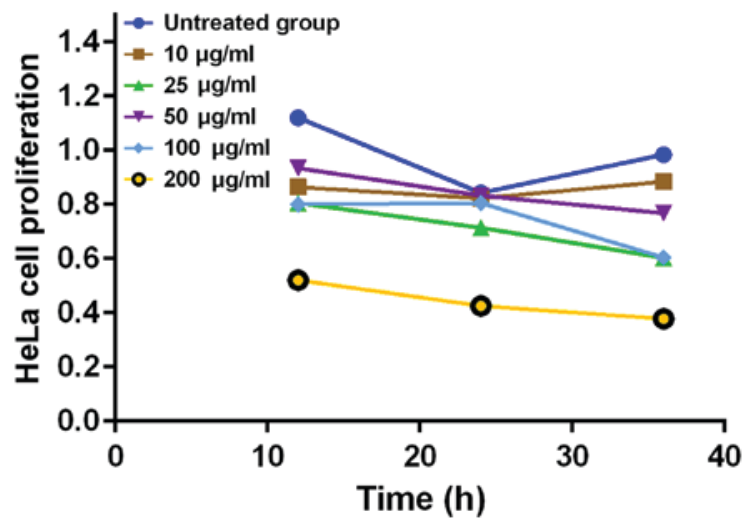

Figure 1. Effects of different concentrations of PM2.5 on HeLa cell proliferation. Compared with NC group, PM2.5 at $10 \mu \mathrm{g} / \mathrm{ml}$ showed no significant effect on cell proliferation, while PM2.5 inhibited the proliferation of HeLa cells at concentrations of 25, 50, 100 and $200 \mu \mathrm{g} / \mathrm{ml}$.

groups by Transwell invasion assay. The results showed that the number of migrating cells in HeLa cells after $10 \mu \mathrm{g} / \mathrm{ml}$ PM2.5 stimulation was significantly higher than that in $\mathrm{NC}$ group $(\mathrm{P}<0.05)$. It could be concluded that an appropriate concentration of PM2.5 could increase the invasion ability of HeLa cells (Fig. 2).

Effects of PM2.5 on the expression levels of IL-1 and IL-6 as detected by western blotting. We detected the expression of IL-1 and IL-6 protein in two groups of cells by western blotting. It was found that the relative expression levels of IL-1 and IL-6 proteins in HeLa cells stimulated by $10 \mu \mathrm{g} / \mathrm{ml}$ PM2.5 for $24 \mathrm{~h}$ were significantly higher than those in HeLa cells of NC group (Fig. 3).

Effects of PM2.5 on the expression levels of IL-1 and IL-6 as detected by RT-qPCR. The expression of IL-1 mRNA and IL-6 mRNA in two groups of cells was detected by RT-qPCR. The relative expression levels of IL-1 mRNA $(2.84 \pm 0.57)$ and IL-6 mRNA $(2.71 \pm 0.31)$ in HeLa cells stimulated by $10 \mu \mathrm{g} / \mathrm{ml}$ PM2.5 were significantly higher that the expression levels of IL-1 mRNA (1.021 \pm 0.171$)$ and IL-6 mRNA $(1.035 \pm 0.023)$ in NC group (both $\mathrm{P}<0.05$ ) (Fig. 4).

Effects of PM2.5 on the levels of IL-1 and IL-6 proteins as detected by ELISA. The expression levels of IL-1 and IL-6 in two groups of cells were detected by ELISA. The expression levels of IL-1 (1.27 \pm 0.33$)$ and IL-6 (1.53 \pm 0.47$)$ in HeLa cells after $24 \mathrm{~h}$ stimulation with $10 \mu \mathrm{g} / \mathrm{ml}$ PM2.5 were significantly higher than the levels of IL-1 $(0.12 \pm 0.04)$ and IL-6 $(0.32 \pm 0.09)$ in NC group $(\mathrm{P}<0.05)$ (Fig. 5). 

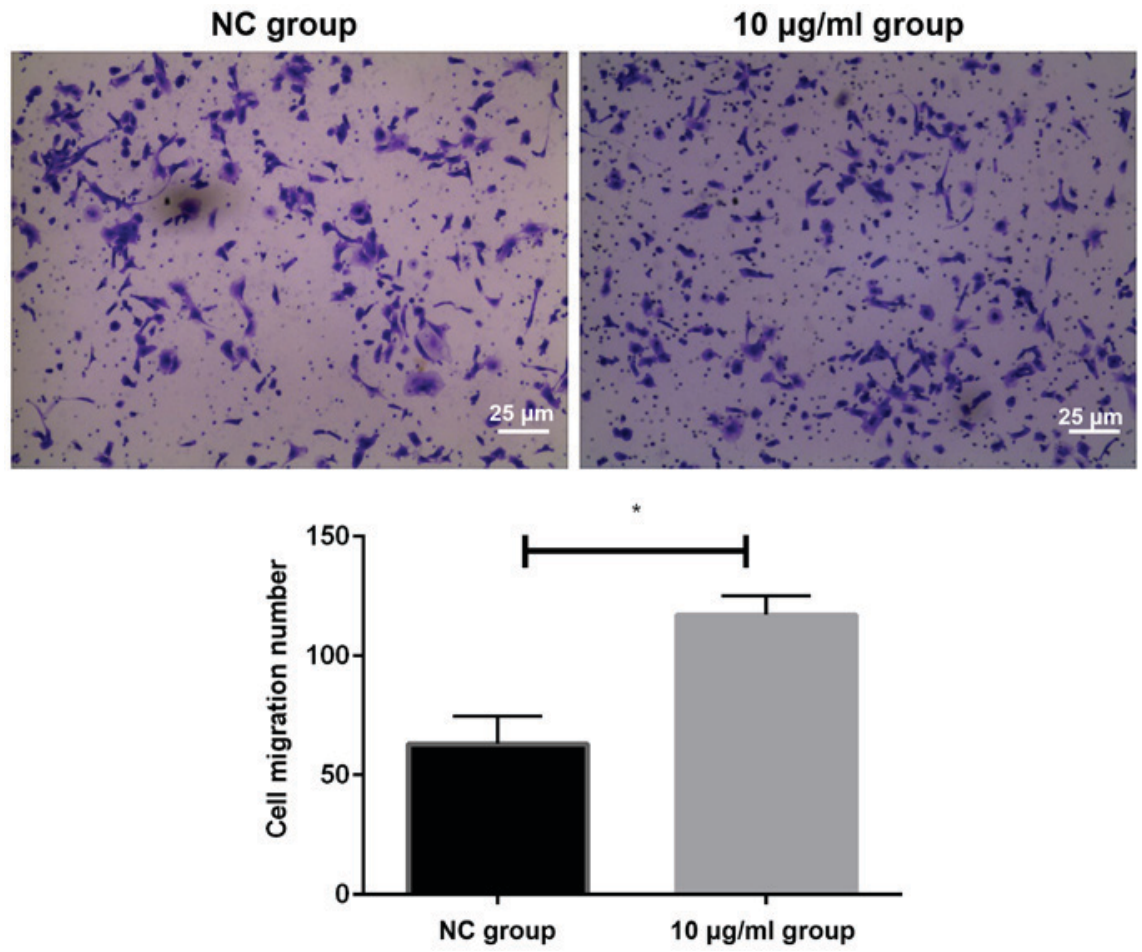

Figure 2. Transwell invasion assay. The cell migration of two groups was observed. H\&E staining showed that compared with control group, the treatment with PM2.5 at $10 \mu \mathrm{g} / \mathrm{ml}$ significantly promoted cell invasion. ${ }^{*} \mathrm{P}<0.05$.
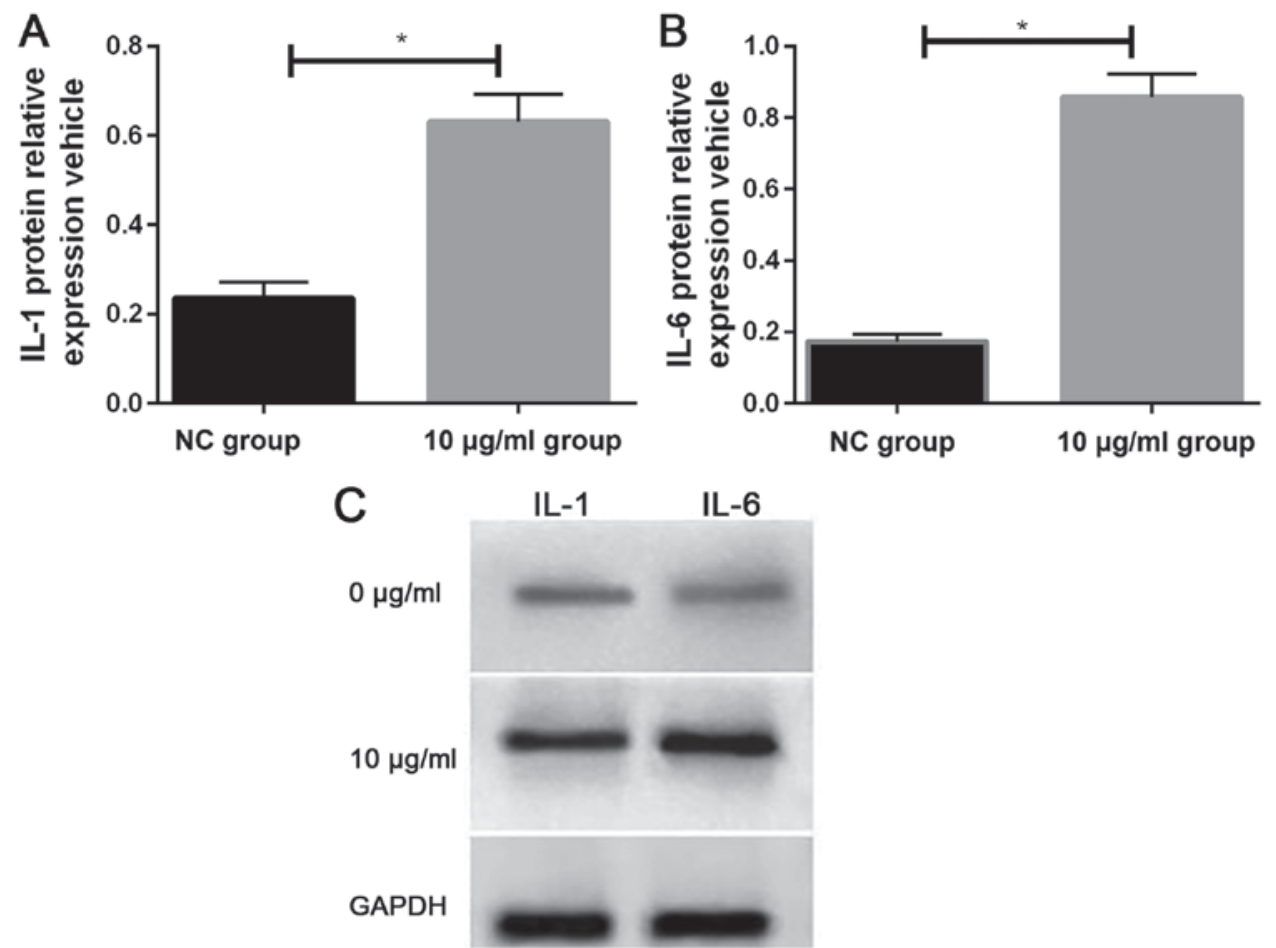

Figure 3. Western blotting. Compared with HeLa cells in NC group, the relative expression levels of (A) IL-1 and (B) IL-6 proteins in HeLa cells treated with $10 \mu \mathrm{g} / \mathrm{ml}$ PM2.5 were significantly increased. (C) Western blots of IL-1 and IL-6 protein in the two groups of cells are shown. "P<0.05.

\section{Discussion}

As the most common carcinogenic substance, PM2.5 exists in the air in the form of solid or liquid. PM2.5 contains harmful and toxic substances that can exist in air for a long time, bringing adverse effects on human health, air quality and environment (15). PM2.5 inhalation affects lung gas exchange, and promotes the occurrence of respiratory diseases, cardiovascular and cerebrovascular diseases, and other diseases such as asthma, arrhythmia and myocardial infarction (16). 

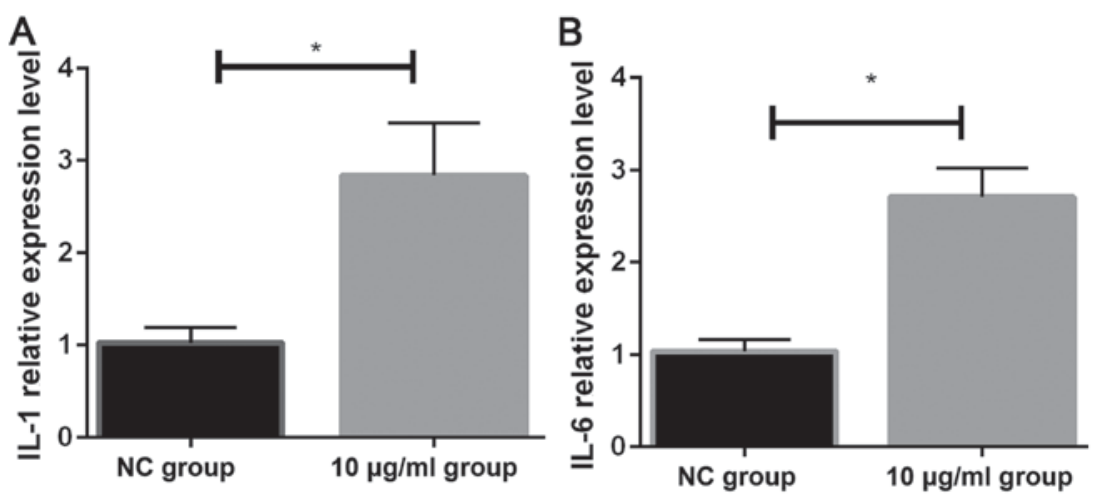

Figure 4. RT-qPCR. The relative expression levels of (A) IL-1 and (B) IL-6 mRNA in HeLa cells treated with $10 \mu \mathrm{g} / \mathrm{ml}$ PM2.5 were significantly higher than those in NC group $(\mathrm{P}<0.05)$. $\mathrm{P}<0.05$.
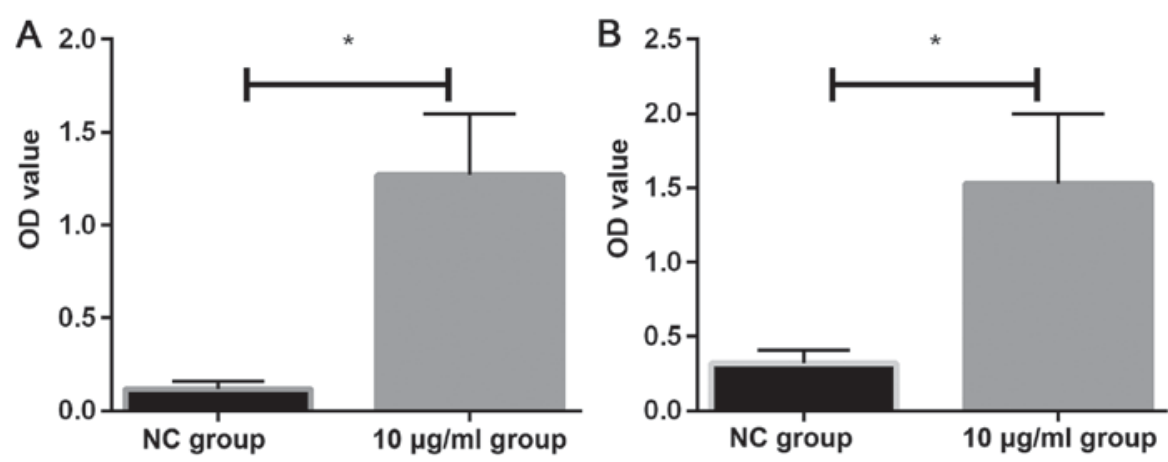

Figure 5. ELISA. ELISA was used to detect the expression of IL-1 and IL-6 in two groups of cells. The OD values of IL-1 and IL-6 in HeLa cells treated with $10 \mu \mathrm{g} / \mathrm{ml} \mathrm{PM} 2.5$ were significantly higher than those in NC group. ${ }^{*} \mathrm{P}<0.05$.

IL-1 is an inflammatory mediator released by activated giant cells and related inflammatory cells. IL-1 can cause infiltration of granulocytes and macrophages, which in turn lead to the occurrence of pulmonary inflammation. IL-1 can be combined with gp130/IL6R to form heterosextrains to stimulate protein tyrosine kinase, leading to the expression of oncogenes and the occurrence of tumorigenesis (17). It has been reported that IL-1 expression levels are significantly lower in normal individuals than those in cervical cancer patients, and studies have shown that IL-1 is a risk factor for cervical cancer $(18,19)$. IL-6 is a multifunctional cytokine, and its receptors belong to the erythroid receptor superfamily which are overexpressed on the surface of non-lymphoid and lymphoid cells. It has been demonstrated (20) that IL-6 can be secreted by both epithelial cells and fibroblasts in the cervical mucosa. IL- 6 not only promotes the proliferation of cervical epithelial cells but also promotes the proliferation of non-tumor-derived HPV-transfected immortalized cells, eventually leading to the transition from cervical lesions to malignant tumors.

HeLa cells are human cervical adenocarcinoma cells. Compared with other cancer cells, HeLa cells have high proliferation ability but the price is low. PM2.5 levels in cities are generally between 8 and $14 \mu \mathrm{g} / \mathrm{m}^{3}$, and high PM2.5 concentrations limit individuals' outdoor activities. Therefore, we selected $10 \mu \mathrm{g} / \mathrm{ml}$ PM2.5 to treat HeLa cells. This study found that the proliferation rate of HeLa cell is negatively associated with PM2.5 concentration. However, PM2.5 at
$10 \mu \mathrm{g} / \mathrm{ml}$ showed no significant effect on proliferation of HeLa cells $(\mathrm{P}>0.05)$, while higher concentrations of PM2.5 inhibited cell proliferation in a concentration-dependent manner. Our finding is consistent with previous studies which have reported that high concentration of PM2.5 can inhibit the proliferation of cells (21). However, Yang et al (22) have reported that high concentration of PM2.5 promotes the proliferation of H1299 cell lines, suggesting that effects of PM2.5 on cell proliferation may be different for different types of cells under the same conditions. Transwell assay showed that, compared with NC group, HeLa cells treated with $10 \mu \mathrm{g} / \mathrm{ml}$ PM2.5 showed significantly increased invasion ability $(\mathrm{P}<0.05)$, indicating that PM2.5 at $10 \mu \mathrm{g} / \mathrm{ml}$ can promote the invasion of $\mathrm{HeLa}$ cells. Invasion ability of HeLa cells is relatively weak, and the increased invasion ability may increase the invasion of tumor cells to surrounding tissues, which in turn increase the degree of malignancy of cervical cancer. RT-qPCR, western blotting and ELISA were performed to detect the expression of IL-1 and IL-6 in HeLa cells treated with PM 2.5 at $10 \mu \mathrm{g} / \mathrm{ml}$. The results of RT-qPCR and western blotting showed that the expression levels of IL-1 and IL-6 in HeLa cells were significantly increased after treatment with PM2.5 at $10 \mu \mathrm{g} / \mathrm{ml}$ for $24 \mathrm{~h}$. However, IL-1 and IL-6 are secretion inflammatory factors and their protein levels usually do not change significantly. Therefore, supernatant of cell culture was collected, and ELISA was performed to detect the levels of IL-1 and IL-6 proteins. Results showed that treatment with PM2.5 at $10 \mu \mathrm{g} / \mathrm{ml}$ significantly increased the secretion levels of IL-1 
and IL-6 proteins. We are unable to perform flow cytometry and $\mathrm{Ki}-67$ because of the limitations of the present funds and conditions. We will try to improve our study in the following research.

In conclusion, this study has preliminarily proven that PM2.5 plays a certain role in the occurrence and development of cervical cancer.

\section{Acknowledgements}

Not applicable.

\section{Funding}

This study was supported by the project of Guangdong Provincial Science and Technology Department 'The effect of PM2.5 exposure on the development and metastasis of cervical cancer and its possible mechanism' (2014A020212687).

\section{Availability of data and materials}

The datasets used and/or analyzed during the current study are available from the corresponding author on reasonable request.

\section{Authors' contributions}

$\mathrm{KH}$ contributed to the cell culture and treatment. WL performed RT-qPCR. YC was responsible for western blotting. KH and JZ assisted with MTT assay. All authors read and approved the final manuscript.

\section{Ethics approval and consent to participate}

The study was approved by the Ethics Committee of the Third Affiliated Hospital of Guangzhou Medical University (Guangzhou, China).

\section{Patient consent for publication}

Not applicable.

\section{Competing interests}

The authors declare that they have no competing interests.

\section{References}

1. Patel MM, Chillrud SN, Correa JC, Hazi Y, Feinberg M, Kc D Prakash S, Ross JM, Levy D and Kinney PL: Traffic-related particulate matter and acute respiratory symptoms among New York City area adolescents. Environ Health Perspect 118: $1338-1343,2010$

2. Turner MC, Krewski D, Pope CA III, Chen Y, Gapstur SM and Thun MJ: Long-term ambient fine particulate matter air pollution and lung cancer in a large cohort of never-smokers. Am J Respir Crit Care Med 184: 1374-1381, 2011.

3. Deng X, Zhang F, Rui W, Long F, Wang L, Feng Z, Chen D and Ding W: PM2.5-induced oxidative stress triggers autophagy in human lung epithelial A549 cells. Toxicol In Vitro 27: 1762-1770, 2013.
4. Lee IM, Bauman AE, Blair SN, Heath GW, Kohl HW III, Pratt M and Hallal PC: Annual deaths attributable to physical inactivity: Whither the missing 2 million? Lancet 381: 992-993, 2013.

5. Hamra GB, Guha N, Cohen A, Laden F, Raaschou-Nielsen O, Samet JM, Vineis P, Forastiere F, Saldiva P, Yorifuji T, et al: Outdoor particulate matter exposure and lung cancer: A systematic review and meta-analysis. Environ Health Perspect 122: 906-911, 2014.

6. Mahalingaiah S, Hart JE, Laden F, Terry KL, Boynton-Jarrett R, Aschengrau A and Missmer SA: Air pollution and risk of uterine leiomyomata. Epidemiology 25: 682-688, 2014.

7. Nursan C, Müge AT, Cemile D, Pinar T and Sevin A: Parent's knowledge and perceptions of the health effects of environmental hazards in Sakarya, Turkey. J Pak Med Assoc 64: 38-41, 2014.

8. Kampa M and Castanas E: Human health effects of air pollution. Environ Pollut 151: 362-367, 2008

9. Al-Tahhan MA, Etewa RL and El Behery MM: Association between circulating interleukin-1 beta (IL-1 $\beta$ ) levels and IL-1 $\beta$ C-511T polymorphism with cervical cancer risk in Egyptian women. Mol Cell Biochem 353: 159-165, 2011.

10. Tanaka T, Narazaki M and Kishimoto T: Interleukin (IL-6) Immunotherapy. Cold Spring Harb Perspect Biol 10: pii a028456, 2018.

11. Wagner JG, Kamal AS, Morishita M, Dvonch JT, Harkema JR and Rohr AC: PM2.5-induced cardiovascular dysregulation in rats is associated with elemental carbon and temperature-resolved carbon subfractions. Part Fibre Toxicol 11: 25, 2014.

12. Christiansen JG, Jensen HE, Jensen LK, Koch J, Aalbaek B, Nielsen OL and Leifsson PS: Systemic inflammatory response and local cytokine expression in porcine models of endocarditis. APMIS 122: 292-300, 2014

13. Dong C, Song WM and Shi YW: Study on the oxidative injury of the vascular endothelial cell affected by PM2.5. Wei Sheng Yan Jiu 34: 169-171, 2005.

14. Andersen CL, Jensen JL and Ørntoft TF: Normalization of real-time quantitative reverse transcription-PCR data: A model-based variance estimation approach to identify genes suited for normalization, applied to bladder and colon cancer data sets. Cancer Res 64: 5245-5250, 2004.

15. Buczyńska AJ, Krata A, Van Grieken R, Brown A, Polezer G, De Wael K and Potgieter-Vermaak S: Composition of PM2.5 and PM1 on high and low pollution event days and its relation to indoor air quality in a home for the elderly. Sci Total Environ 490: 134-143, 2014.

16. Zhao Y, Lin Z, Jia R, Li G, Xi Z and Wang D: Transgenerational effects of traffic-related fine particulate matter (PM2.5) on nematode Caenorhabditis elegans. J Hazard Mater 274: 106-114, 2014.

17. Sparmann A and Bar-Sagi D: Ras-induced interleukin-8 expression plays a critical role in tumor growth and angiogenesis. Cancer Cell 6: 447-458, 2004.

18. Qian N, Chen X, Han S, Qiang F, Jin G, Zhou X, Dong J, Wang X, Shen $\mathrm{H}$ and $\mathrm{Hu} \mathrm{Z}$ : Circulating IL-1beta levels, polymorphisms of IL-1B, and risk of cervical cancer in Chinese women. J Cancer Res Clin Oncol 136: 709-716, 2010.

19. Song Z, Lin Y, Ye X, Feng C, Lu Y, Yang G and Dong C: Expression of IL-1 $\alpha$ and IL-6 is associated with progression and prognosis of human cervical cancer. Med Sci Monit 22: 4475-4481, 2016

20. Dayalu Naik SL, Kumar V and Joshi R: HPV Inflammation mediate IL-6 through STAT3 signaling pathway in different grades of cervical cancer. J Cancer Res Molecul Med 3: 1-5, 2016.

21. Alfaro-Moreno E, Torres V, Miranda J, Martínez L, García-Cuellar C, Nawrot TS, Vanaudenaerde B, Hoet P, Ramírez-López P, Rosas I, et al: Induction of IL-6 and inhibition of IL-8 secretion in the human airway cell line Calu-3 by urban particulate matter collected with a modified method of PM sampling. Environ Res 109: 528-535, 2009.

22. Yang B, Chen D, Zhao $\mathrm{H}$ and Xiao C: The effects for PM2.5 exposure on non-small-cell lung cancer induced motility and proliferation. Springerplus 5: 2059, 2016.

This work is licensed under a Creative Commons Attribution-NonCommercial-NoDerivatives 4.0 International (CC BY-NC-ND 4.0) License. 